\title{
THE EFFECT OF TRANSACTION COST ECONOMICS ON HYBRID CORN FARMING INCOME IN CIHAUR VILLAGE MAJA SUBDISTRICT MAJALENGKA REGENCY
}

\author{
Vina Rachmadina*)1, Zumi Saidah*), Lucyana Trimo*), and Eliana Wulandari*) \\ ${ }^{*}$ Department of Social and Agricultural Economics, Faculty of Agriculture, Padjadjaran University \\ Jl. Raya Bandung-Sumedang KM 21 Jatinangor Sumedang 45363
}

\begin{abstract}
Transaction costs on corn farming can affect the income of corn farming. This research aimed to identify the transaction cost economics (TCE) structure and analyze the effect of TCE on the income of hybrid corn farming. The research method used is TCE analysis and multiple linear regression analysis. This research was conducted in Cihaur Village, Maja Subdistrict, Majalengka Regency, West Java, on 64 respondents. The research results showed that the transaction cost economics component on hybrid corn farming consists of (1) information cost; (2) negotiation cost; (3) coordination cost; (4) implementation cost; and (5) risk cost. The amount of the transaction cost that is formed on hybrid corn farming was Rp105,421.16. The percentage of transaction cost to total production cost was $2,78 \%$. Coordination costs consisted of meeting cost, and farmer group fees have the highest transaction costs component, leading to $41,96 \%$. On the other hand, risk cost has the lowest prices, merely 3,09\%, in which there are avoiding risk cost and controlling risk cost. The results showed that the seven variables tested had significant effects on the income of corn farming. These variables included land area, fertilizer costs, seed costs, selling price, labor wages, productivity, and transaction cost.
\end{abstract}

Keywords: income, farming, hybrid corn, production cost, transaction cost

\begin{abstract}
Abstrak: Biaya transaksi pada usahatani jagung memiliki pengaruh terhadap tinggi rendahnya pendapatan usahatani jagung. Penelitian ini bertujuan untuk mengidentifikasi struktur biaya transaksi dan menganalisis pengaruh biaya transaksi terhadap pendapatan usahatani jagung hibrida. Metode penelitian yang digunakan adalah transaction cost analysis dan analisis regresi linear berganda. Penelitian ini dilakukan di Desa Cihaur, Kecamatan Maja, Kabupaten Majalengka, Provinsi Jawa Barat terhadap 64 responden petani. Hasil penelitian menunjukkan bahwa komponen ekonomi biaya transaksi pada usahatani jagung hibrida di Desa Cihaur terdiri dari (1) biaya informasi; (2) biaya negosiasi; (3) biaya koordinasi; (4) biaya pelaksanaan; dan (5) biaya risiko. Jumlah biaya transaksi yang terbentuk pada usahatani jagung adalah sebesar Rp105,421.16. Rasio biaya transaksi terhadap total biaya produksi adalah sebesar 2.78\%. Biaya koordinasi yang di dalamnya terdapat biaya rapat dan biaya iuran kelompok tani memiliki persentase tertinggi sebesar $41.96 \%$ dan biaya risiko memiliki persentase terendah sebesar 3.09\% yang terdiri dari biaya menghindari risiko dan biaya mengendalikan risiko. Hasil penelitian menunjukkan bahwa tujuh variabel yang diuji berpengaruh nyata terhadap pendapatan usahatani jagung. Seluruh variabel tersebut meliputi luas lahan, biaya pupuk, biaya benih, harga jual, upah tenaga kerja, produktivitas, dan biaya transaksi.
\end{abstract}

Kata kunci: biaya produksi, biaya transaksi, jagung hibrida, usahatani, pendapatan

\footnotetext{
${ }^{1}$ Corresponding author:

Email: vina17001@mail.unpad.ac.id
} 


\section{INTRODUCTION}

Theagricultural sector, especiallythefoodcropsubsector, became an important sector with the establishment of increased availability of food sourced from within the country, especially for staple goods commodities such as rice, corn, and soybeans, as the main target of strengthening food supply and diversifying food consumption (Haris et al. 2018). Indonesia is one of the ten countries with the largest availability of corn for consumption in the world in 2013 - 2018, with an average corn supply of 12,200 tons (Pusdatin, 2018). Half of corn's current use is the main raw material of the animal feed industry, with consumption in 2017 reached 12.7 tons, and the following year, it increased to 13.8 million tons. The selection of corn farming as the object of this research is that corn is a type of cereals or food crops and raw materials for animal feed with high economic value to affect farming income (Bantacut et al. 2015). Farmers cannot enjoy the benefits of farming due to high production costs and other costs that are difficult to identify by farmers, namely transaction costs (Saidah et al. 2019).

Transaction costs of exchange are a characteristic inherent in an institution in which there are farmers as one of the institutional administration elements that do not have full access and control over the determination of the value and transaction costs (Sucihatiningsih \& Waridin, 2010). Transaction costs are often be ignored by businesses due to limited information and lack of knowledge to identify and calculate the cost of such transactions (Baye, 2010). Market failures that lead to the need for non-markets stem from imperfect information, production externalities, and identifying public goods. Institutional failures that are the cause of economic backwardness in many countries refer to contract structures and laws that should be strengthened to carry out market transactions (Vipriyanti, 2018). Can minimize transaction costs, and farmers will benefit from farmers can identify the costs incurred from each transaction (Williamson, 2000).

Transaction costs arise due to conditions in which the market fails to provide market needs efficiently due to lack of information (Fadhiela et al. 2018). Small farmers' participation in the market is still relatively low due to several constraints such as poor market access, lack of means to overcome the cost of entering the market due to high transaction costs, poor infrastructure, and weak institutions (Otekunrin et al. 2019). Transaction costs tend to be hidden and ignored by farmers because they are not considered costs, even though they can affect revenue and decrease competitiveness (Ginting et al. 2018). The structure of transaction costs in farming activities from planting to harvesting occurs in the procurement of financing sources and procurement of inputs (Sultan \& Rachmina, 2016). The most efficient and highest marketing channel profit ratio value is the channel with the lowest transaction costs. The higher transaction costs incurred by farmers will reduce farmers' profits and affect farm income (Rachman et al. 2017).

Saidah et al. (2019) stated that the transaction costs structure identified consists of information search costs, implementation costs, partner search costs, and negotiation costs. Transaction costs are one factor that can reduce the profit of red chili farming. The transaction costs structure of each research will give different results because of the differences in research objectives, and targets which are determined by the size of land area, farm-scale management in each farmer's household and what types of transaction costs are contained in the farm (Saidah et al. 2019). Transaction costs in hybrid corn farming are still relatively high, impacting low farm income (Mohamad et al. 2014). Yustika (2008) classifies transaction costs with the following variables: (i) market transaction costs; (ii) managerial transaction costs; (iii) political transaction costs. Based on the research done related to transaction costs, this study identifies how transaction cost economics (TCE), ranging from input procurement to harvesting, can affect farmers' income in hybrid corn commodities by showing factors that affect farm income.

Transaction costs are difficult to avoid. It causes farmers' economic pressure due to a large surplus paid from farmers to other parties to decrease (Anggraeni et al. 2014) directly. Farmers' participation in the capital search is expected to lead to transaction costs that will later affect the level of farm profits. The higher the transaction costs, the lower the profit will be and vice versa. Farmers are difficult to identify transaction costs that will impact the profits of the farm itself. However, if the transaction costs can be appropriately identified, this can improve the business and control the profits (Sultan \& Rachmina, 2016). Transaction costs, referred to as hidden costs, are the observable and nonappreciable costs associated with exchanging goods and services (Adenengan et al. 2013). Transaction costs in 
farming are related to three main things: contracts and property rights issues, organizational and institutional arrangements, and market exchanges (Saidah et al. 2019). Decision-making in production, labor allocation, and consumption are affected by transaction costs (Elly, 2009). The low level of farmers' awareness of transaction costs makes it difficult to classify the costs to be incurred to reduce the income received by farmers because they unconsciously spent other costs outside production costs that are not considered (Berge et al. 2015). Based on this problem, this study aims to (1) identify the transaction cost economics (TCE) structure in hybrid corn farming; and (2) analyze the factors that affect the transaction cost economics (TCE) structure to the income of hybrid corn farming.

This research uses the survey method with a quantitative research design with a limited scope. The research was carried out by individual farmers who planted hybrid corn commodities in Cihaur Village, Maja Subdistrict, Majalengka Regency. The transaction costs component examined in this study is only the cost paid by farmers starting from the search for capital to the expected harvest to identify transaction cost economics. Farmers can find out the costs paid in addition to production costs so that efforts can be made to minimize transaction costs to increase farm income. TCE can be reduced by identifying the structure of transaction costs divided into three groups: capital search costs, farm management costs, and harvesting costs, which contain several components of transaction costs. This study has not yet identified further related transaction costs in the marketing process to consumers.

\section{METHODS}

The object of this study is the structure of transaction cost economics in hybrid corn farming and the factors that can affect the income of hybrid corn farming. The research was conducted on hybrid corn farming precisely in Cihaur Village, Maja Subdistrict, Majalengka Regency, West Java Province. The research location was chosen with the consideration that Majalengka Regency is one of the largest production centers for corn commodities in West Java Province (BPS, 2018). This research was conducted in August 2020. The type of data used is cross-section data in 2020. The primary data was obtained through in-depth interviews and questionnaires by respondents, namely farmers who do hybrid corn farming in the form of transaction cost economics structure and production costs data. This study also uses secondary data obtained from the Central Statistics Agency, The Ministry of Agriculture, journals, and other official publication documents in the form of farmers' population, land area, production, and productivity data in the research location.

This study uses a probability sampling technique with simple random sampling. The respondents were selected randomly with 64 respondents who were hybrid corn farmers in Cihaur Village, Maja Subdistrict, Majalengka Regency. To identify TCE faced by farmers can be analyzed by calculating the total of each transaction costs component $(\tau \mathrm{rC})$ with the following formula:

$$
\tau \mathrm{rC}=\sum \mathrm{Z}_{\mathrm{ij}}
$$

The ratio of each component of transaction cost to total transaction cost was calculated using the following formula:

$$
\mathrm{Z}=\mathrm{Z}_{\mathrm{ij}} / \operatorname{TrC} ; \sum \mathrm{Z}_{\mathrm{ij}}=1
$$

To calculate the percentage of transaction costs to total cost of farming is intended to see the proportion of transaction costs to the total cost of farming using the equation as formula:

$$
\mathrm{rtc}_{\mathrm{j}}=(\tau \mathrm{rc} /(\tau \mathrm{c}+\tau \mathrm{rc})) \times 100
$$

in which: $\tau \mathrm{rC}=$ total transaction costs, $\mathrm{Z}=$ ratio of transaction cost components, $\mathrm{zij}=$ transaction cost component (i.e information costs, negotiation costs, coordination costs, implementation costs and risk costs), $\mathrm{rtc}_{\mathrm{j}} \mathrm{j}=$ ratio of transaction costs to farming costs, $\tau \mathrm{c}=$ total production cost.

This study aims to analyze the factors that affect the income of hybrid corn farming by using multiple linear regression analysis. Hybrid corn farming income (INCOME) was presumably affected by land area (LAND), fertilizer costs (FERTIC), seed costs (SEEDC), labor wages (LABOR), productivity (PRODV), and transaction costs (TRANSC). This analysis was useful to examine the factors that affected the income of hybrid corn farming as follows:

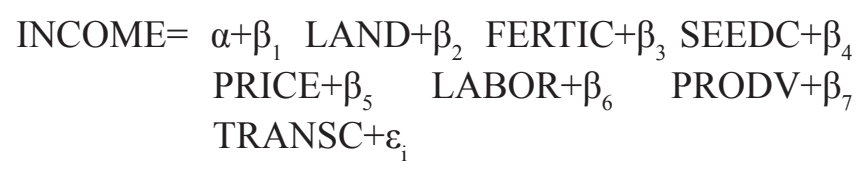


In which: $\alpha$ (constanta), $\beta$ (coefficient of regression), $\beta_{1} \ldots \beta_{7}$ (regression coefficients for each independent variable), $\varepsilon_{\mathrm{i}}$ (standard error).

Based on the theoretical exemplifications, the hypotheses of this study were: (1) transaction cost economics structure contained in hybrid corn farming consists of information costs, negotiation costs, implementation costs, coordination costs, and risk costs; (2) land area, fertilizer cost, seed cost, labor wage, productivity, and transaction costs were considered to have a significant effect on the hybrid corn farming income.

Market failure occurs in farming in the form of farmers' inability to obtain inputs such as fertilizers and seeds following the government's price due to the high TCE that occurs in farming that cannot be identified independently by farmers. The importance of institutional in helping farmers get the infrastructure in farming management is social capital. Social capital is one of the important things in farming so that farmers can reduce prices in a transaction ranging from the procurement of inputs to harvesting so that it will reduce the TCE. Factors that affect farm income include land area, fertilizer cost, seed cost, selling price, labor wage, productivity, and transaction cost. The transaction costs are divided into three parts, including the costs paid at the time of the capital search, farm management and harvesting. The three costs are divided into several components of transaction costs contained in it, namely the cost of capital search including information costs, negotiation costs, and implementation costs; the cost of farm management consists of information costs, negotiation costs, and coordination costs; and the cost of harvesting consists of information costs and risk costs. The TCE structure, which has been identified and known, is expected to help farmers reduce high costs to increase farm income. Research framework in Figure 1.



Figure 1. Research framework 


\section{RESULTS}

\section{Hybrid Corn Farming in Cihaur Village}

Based on the results, hybrid corn farming in Maja Subdistrict is concentrated in several villages. One of the villages that are the center of corn is Cihaur Village, with an average production of $2,865 \mathrm{~kg}$ and a selling price of Rp3,386 per kg. Land area and farming costs can affect farmers' profits (Sultan \& Rachmina, 2016). The average land area owned by farmers in Cihaur Village with brown regosol soil type and located in the highlands is 0.77 ha, where most of the land is owned by farmers. In maximizing the land, farmers incur costs that will affect the farm income itself (Purwanto et al. 2015). In carrying out their farming, farmers can not be separated from incurred and calculated costs to produce hybrid corn. Production costs in agriculture are divided into fixed and variable costs (Susianti \& Abd Rauf, 2013). The calculation of production costs will show the amount of income earned in farming. Farm income is divided into cash costs and total costs (Normansyah et al. 2014). The average production cost paid by farmers in Cihaur Village is Rp3,686,567.97. Income and R/C Ratio of Hybrid Corn Farming in Cihaur Village can be seen in Table 1.

Table 1 shows that hybrid corn farming with or without transaction costs is feasible and profitable to be cultivated $(\mathrm{R} / \mathrm{C}$ Ratio $>1)$. The results of the research also show that R/C Ratio $>1$ shows the effectiveness of capital turnover. It is following the study conducted by Tahir \& Suddin (2017) on The Analysis of Corn Farming Income on Rice Fields and Moors in Ulaweng Subdistrict, which obtained the ratio of corn farming $\mathrm{R} / \mathrm{C}$ on rice fields and moors worth $>1$ so that the farm is said to be feasible and profitable.

\section{The Structure of Transaction Cost Economics (TCE) on Hybrid Corn Farming}

The TCE structure on hybrid corn farming is divided into several groups ranging from capital search to harvesting. The transaction cost component of the capital search cost consists of information costs, negotiation costs, and implementation costs. The components in the cost of farm management consist of information costs, negotiation costs, and coordination costs. The transaction cost component at harvesting time consists of information costs and risk costs. The distribution of the TCE group that directly affects the farmer's expense is described as follows.

In the TCE structure in the search for hybrid corn farming capital in Cihaur Village, Maja Subdistrict appears before farming. Farmers collect capital first, which is obtained from both internal and external sources consisting of information costs, negotiation costs, and implementation costs, as shown in Table 2. $\mathrm{R} / \mathrm{C}$ ratio $>1$ shows that corn farming is feasible and profitable and shows the effectiveness of capital turnover, which is also good.

Table 1. Income and R/C Ratio of Hybrid Corn Farming in Cihaur Village, 2020

\begin{tabular}{lcc}
\hline Variable & Unit & Amount \\
\hline Hybrid corn production & $\mathrm{Kg}$ & 2,865 \\
Hybrid corn price & $\mathrm{Rp} / \mathrm{kg}$ & $3,385.94$ \\
Hybrid corn revenue (production x price) & $\mathrm{Rp}$ & $9,757,359.38$ \\
Hybrid corn production cost & $\mathrm{Rp}$ & $3,686,567.97$ \\
Hybrid corn transaction cost & $\mathrm{Rp}$ & $105,421.16$ \\
Total cost of hybrid corn farming & $\mathrm{Rp}$ & $3,791,989.13$ \\
Income on production costs & $\mathrm{Rp}$ & $6,070,791.41$ \\
Income on total costs & $\mathrm{Rp}$ & $5,965,370.25$ \\
\hline $\mathrm{R} / \mathrm{C}$ revenue on production costs & & 2.65 \\
\hline $\mathrm{R} / \mathrm{C}$ revenue on total costs & & 2.57 \\
\hline
\end{tabular}


In Table 2, it can be seen that the transaction cost component in the search for hybrid corn farming capital with the highest percentage is in the implementation costs of $66.04 \%$, which includes waiting for costs. Farmers pay this cost during disbursing capital loans or costs lost when farmers do not do their farming. Fadhiela et al. (2018) also proved that the transaction cost with the highest percentage is the opportunity cost. On a farm, there is a cost sacrificed as a result of leaving the primary job calculated based on the time spent going to the main job or farming. Masithoh (2016) state that opportunity cost arises because farmers sacrifice other jobs when transactions are carried out during the working period so that farmers have to pay the loss costs. The lowest percentage of capital search transaction costs is the negotiation costs of $11.27 \%$. Negotiation costs consist of the charge of coordinating when farmers negotiating or bargaining with the source of capital. Suppose there is an incompatibility in the loan amount between farmers and the source of capital. In that case, bargaining carried out until there is an agreement regarding the amount of capital to be borrowed. Farmers will coordinate by communication using communication media or coming directly to the source of the capital's location. Some costs must be paid, such as pulse costs, consumption costs, and transportation costs included in the negotiation costs.

Doing their farming, farmers paid other costs besides production costs. These costs are included in the transaction costs in farm management, consisting of information costs, negotiation costs, and coordination costs, as shown in Table 3. The transaction costs component in the management of hybrid corn farming with the highest percentage is the coordination costs of $64.81 \%$, consisting of the meeting cost of farmer groups and the cost of farmer group fees. When conducting regular meetings of farmer groups, farmers will spend in the form of transportation costs to the meeting place and consumption costs. Farmers who spend this cost are only farmers who join farmer groups. Another cost is the cost of farmer group fees that are usually paid by farmers who are members of the farmer group, which are paid once a year. The lowest percentage is the information fee of $13.77 \%$. Information costs paid by farmers on the hybrid corn farm management are labour information costs and farming information costs. Zulkarnain \& Mangiring (2017) also state that the cost of finding information has the lowest percentage because the existence of active farmer group meetings can make fewer information costs. The purpose of the group is to share information to increase knowledge and information used as a basis for decision-making by members of the farmer groups. When entering the harvest season, farmers do several activities that will incur transaction costs. These costs will affect the selling price of hybrid corn, and unconsciously, the higher the TCE at harvest time, will cause the selling price of hybrid corn to be lower. The structure of TCE on hybrid corn farming harvest in Cihaur Village, Maja Subdistrict consisting of information costs and risk costs can be seen in Table 4.

Table 2. Average transaction cost in hybrid corn farming capital

\begin{tabular}{lcc}
\hline Types of Transaction Costs & Amount (Rp/year) & Percentage (\%) \\
\hline Information cost & $7,042.86$ & 22.69 \\
Negotiation cost & 3,500 & 11.27 \\
Implementation cost & 20,500 & 66.04 \\
Total of transaction costs & $31,042.86$ & 100 \\
\hline
\end{tabular}

Table 3. Average transaction cost in hybrid corn farming management

\begin{tabular}{lcc}
\hline Types of Transaction Costs & Amount (Rp/year) & Percentage (\%) \\
\hline Information cost & $9,397.60$ & 13.77 \\
Negotiation cost & $14,619.05$ & 21.42 \\
Coordination cost & $44,236.61$ & 64.81 \\
Total of transaction costs & $68,253.26$ & 100 \\
\hline
\end{tabular}


In Table 4, it can be seen that the transaction costs component with the highest percentage is the risk costs of $53.14 \%$, consisting of the cost of avoiding risk and the cost of controlling risk. When selling their crops, farmers usually bring crops to the dealer or middlemen. During the trip, sometimes there is hybrid corn that is damaged, especially when it rains unexpectedly. Some farmers anticipate preparing plastic or tarp to protect the corn while it is on the way. These costs included in the cost of avoiding the risk of damaged corn. If the corn carried by farmers is damaged upon arrival at the buyer's place, it will reduce the price received from the actual price, known as the cost of controlling risk. The lowest percentage of transaction costs component is the information costs of $46.86 \%$. Farmers spend the cost of information because farmers' location is far from the source of information. They have to spend costs such as phone credit cost when communicating and transportation costs when visiting the information costs directly.

The total TCE paid by farmers in hybrid corn farming in one year is Rp105,421.16 per 0.77 ha. In their research, Sultan \& Rachmina (2016) identified the number of transaction costs in soybean farming is Rp.144,120.86 per year. It shows that TCE on hybrid corn farming in this research still relatively low. The transaction cost component for all activities ranging from capital search, farming management to harvesting is dominated by coordination costs with a percentage of $41.96 \%$. The amount of coordination costs in which there are meeting costs and farmer group fees is caused by the high cost paid by farmers who join the farmer group when attending meetings or paying annual fees. It is similar to the research conducted by Zulfiandri et al. (2017) 's research in analyzing transaction costs on the vertical integration of small-scale cocoa agroindustry value chains. It obtained that the costs borne by the group were the highest percentage of transaction costs. Zulkarnain et al. (2019) found that the structure of transaction costs with the highest percentage obtained in cassava farming. It happens because farmers continued to do farming planning, procurement of farming inputs, and farm management. Transaction costs will increase total production costs. The less the amount of transaction costs so the less the total price paid by farmers. It follows the research results in which transaction costs on the management of farming have the highest amount compared to transaction costs on capital search and harvest. TCE for hybrid corn farming in Cihaur Village, Maja Subdistrict is shown in Table 5. The percentage of TCE paid by farmers in doing hybrid corn farming is $2.78 \%$ to the total production costs, which is calculated based on the division between transaction costs and the difference between production costs and transaction costs multiplied by 100 .

Table 4. Average transaction cost on hybrid corn farming harvest

\begin{tabular}{lcc}
\hline Types of Transaction Costs & Amount (Rp/year) & Percentage (\%) \\
\hline Information cost & $2,870.49$ & 46.86 \\
Risk cost & $3,254.55$ & 53.14 \\
Total of transaction costs & $6,125.04$ & 100 \\
\hline
\end{tabular}

Table 5. The total transaction cost economics on hybrid corn farming

\begin{tabular}{lccccc}
\hline $\begin{array}{l}\text { Type of Cost } \\
\text { Transaction }\end{array}$ & $\begin{array}{c}\text { Capital Search } \\
\text { (Rp/year) }\end{array}$ & $\begin{array}{c}\text { Farm } \\
\text { Management } \\
\text { (Rp/year) }\end{array}$ & $\begin{array}{c}\text { Harvest } \\
\text { (Rp/year) }\end{array}$ & $\begin{array}{c}\text { Amount } \\
\text { (Rp/year) }\end{array}$ & $\begin{array}{c}\text { Percentage } \\
(\%)\end{array}$ \\
\hline Information cost & $7,042.86$ & $9,397.60$ & $2,870.49$ & $19,310.95$ & 18.32 \\
Negotiation cost & $3,500.00$ & $14,619.05$ & - & $18,119.05$ & 17.19 \\
Coordination cost & - & $44,236.61$ & - & $44,236.61$ & 41.96 \\
Implementation cost & $20,500.00$ & - & - & $20,500.00$ & 19.45 \\
Risk cost & - & - & $3,254.55$ & $3,254.55$ & 3.09 \\
Total of transaction costs & & & & $105,421.16$ & 100 \\
\hline
\end{tabular}




\section{The Effect of Transaction Cost on the Income of Hybrid Corn Farming}

The next objective is to find out how TCE affects the income of hybrid corn farming. The result of estimating the parameters of farm income equation by using multiple linear regression analysis, can be seen in Table 6 which shows that all variables significantly affect farm income at the level of $10 \%$.

These variables include transaction costs: the farmers' total costs and the production costs whose existence was not realized by the farmers. Transaction costs had a negative and significant effect of 0.034 on hybrid corn farming income. This is following research conducted by Sultan \& Rachmina (2016); Saidah et al. (2019), those transaction costs have a negative and significant effect on the farm profits and revenues, which indicates that the higher the transaction costs paid by farmers, will reduce the profits and revenues of the farmers. Leonardo et al. (2015) state that transaction costs' contribution is limited because it only applies to individual prices and farmers transaction.

The land area has a positive effect on the farm income, which indicates that the larger the land area owned by farmers will increase farmers' income. The variable of fertilizer costs negatively affects farmers' income. The more cost paid by farmers will reduce the farm income. The high fertilizer cost paid by farmers caused by the increase in the fertilizer prices that farmers get while buying it. When farmers purchase fertilizer at a high price will cause more costs to spend so that farm income will decrease. Seed costs variable have a negative and significant effect on farm income, indicating that the increase of seed prices will reduce hybrid corn farming income. The seed is a very important thing to note because it is one of the determinants of a farm's production quality (Isnanda et al. 2017). Seeds used in hybrid corn farming are BISI - 18 variety. The use of BISI-18 hybrid corn seeds has advantages against leaf rust and leaf disease. In addition to the potential for harvest, BISI-18 seeds can reach an average of 12 tons per hectare of the dry shell. In comparison, other types of seeds produced are only 9.1 tonnes per ha of the dry shell (Department of Plants and Food, 2016).

The selling price variable has a positive effect, indicating that the higher the farmers' price will increase the farm income. Labor wage variables negatively affect farm income. The more labor used will increase the costs of paying labor wages to decrease the farm income earned. The effective and efficient use of labor can affect farming's income (Gustiana \& Irwanto, 2017). The productivity variable has a positive effect on farm income, indicating that hybrid corn farming's high productivity will increase income.

\section{Managerial Implications}

Based on the research results, it can be known that farmers still have limitations in processing information and the absence of concentration of activities at one point that causes market failure. Information imperfections can result in different transaction cost economics for each farmer. There needs to be an institutional role in the form of farmer groups that has a perfect bargaining power of farmers, strong capital, and a large market by improving the existing system inside. To reduce transaction costs by improving the government's facilities so that farmers are more active in participating in farmer groups and necessary management in structured farming activities to occur centralizing activities.

Table 6. Results of parameter estimation of the income equation of hybrid corn farming

\begin{tabular}{lcccc}
\hline Variable & Estimation Parameters & Standard Error & T Value & P-Value \\
\hline Land Area (X1) & $1.43 \times 10^{7}$ & 521484.6 & 27.38 & 0.000 \\
Fertilizer cost (X2) & -5.550141 & .8643394 & -6.42 & 0.000 \\
Seed cost (X3) & -2.24161 & 1.186857 & -1.89 & 0.064 \\
Selling price (X4) & 4890.879 & 2531.925 & 1.93 & 0.058 \\
Labor wages (X5) & -1.00954 & .5934246 & -1.70 & 0.094 \\
Productivity (X6) & 2877.454 & 316.885 & 9.08 & 0,000 \\
Transaction cost (X7) & -41.64049 & 19.14096 & -2.18 & 0.034 \\
\hline \multicolumn{5}{c}{ Number of Obs } \\
\hline
\end{tabular}

Note: Significant at 10\% 


\section{CONCLUSIONS AND RECOMMENDATIONS}

\section{Conclusions}

The structure of transaction cost economics (TCE) in hybrid corn farming in Cihaur Village, Maja Subdistrict, Majalengka Regency consists of: capital search costs, farm management costs, and harvest costs in which there are information costs, negotiation costs, coordination costs, implementation costs, and risk costs. The number of transaction costs on hybrid corn farming per 0,77 ha per year is still relatively low, with a percentage of $2.78 \%$ to the total production costs. Coordination costs in which there are meeting costs and farmer group fees have the highest percentage while risk costs have the lowest risk avoidance and risk control costs. Factors that affect farm income are land area, fertilizer cost, seed cost, selling price, labor wage, productivity and transaction cost. Transaction costs have a negative and significant influence on farm income, which indicates that the higher the transaction costs paid will reduce farmers' income. .

\section{Recommendations}

A robust institutional level is required for farmers by actively engaging in farmer groups for each farming activity, not only at assistance from related parties. As an institution, farmer groups with revitalization and reorientation are expected to strengthen farmers' bargaining power, strengthen capital, and expand the scope of marketing, leading to increased farm income. Farmer groups should also have a strong relationship among farmers, good organizational structure, clear tasks and functions, and coordination systems. Besides, there is a need to provide knowledge from agricultural extension workers to be more aware of the existence and reduce transaction costs with the facilities provided. Fee payment system and farmer group meetings must be improved and utilized as best as possible to reduce coordination costs which is the highest in this research. For further study, it is expected to identify transaction costs in hybrid corn farming in Cihaur Village by comparing transaction costs paid by farmers with or without following farmer groups.

\section{REFERENCES}

Adenengan KO, Olorunsomo SO, Nwauwa LOE. 2013. Determinants of market orientation among smallholders cassava farmers in Nigeria. Global Journal of Management and Business Research Finance 13(6): 1-11.

Anggraeni NLV, Muhammad AZM, Bambang SH. 2014. Perandan koordinasi stakeholder dalam pengembangan kawasan minapolitan di Kecamatan Nglegok Kabupaten Blitar. Jurnal Administrasi Publik 3(12): 2070-2076.

[BPS] Badan Pusat Statistik. 2018. Kabupaten Majalengka Dalam Angka Tahun 2018. Majalengka: BPS.

Bantacut T, Muammar TA, Yasser RF. 2015. Pengembangan jagung untuk ketahanan pangan, industri dan ekonomi. Jurnal Pangan 24(2): 135 $-148$.

Baye MR. 2010. Managerial Economics and Business Startegy 7th Edition. New York: Mc Graw-Hill Irwin.

Berge LIO, Bjorvatn K, Tungodden B. 2015. Human and financial capital for microenterprise development: evidence from a field and lab experiment. Management Science Journal 61(4): 707-722. https://doi.org/10.1287/ mnsc.2014.1933.

Dinas Tanaman dan Pangan. 2016. Penggunaan Pupuk SP-36 Meningkatkan Produksi Tanaman Jagung di Desa Candimulyo. Retrieved from Dinas Tanaman dan Pangan Kabupaten Magelang: https://distanpangan.magelangkab. go.id/home/detail/penggunaan-pupuk-sp-36meningkatkan-produksi-tanaman-jagung-didesa-candimulyo/130\#: : text=Jagung $\% 20$ h i b rida \% 20 B I S I \% 2 D $18 \% 20$ mempunyai,filling)\%20bisa\%20mencapai $\% 20$ $97 \% 25$.

Fadhiela K, Rachmina D, Winandi R. 2018. Biaya transaksi dan analisis keuntungan petani pada sistem resi gudang kopi arabika gayo di Kabupaten Aceh Tengah. Jurnal Agribisnis Indonesia 6(1): 49-60. https://doi.org/10.29244/ jai.2018.6.1.49-60.

Ginting LN, Kusnandi N, Pambudy R. 2018. Biaya transaksi eksplisit dan implisit dalam usaha ternak sapi perah di Kabupaten Bandung Barat. Jurnal Ilmu Pertanian Indonesia (JIPI) 23(2): 246-258. https://doi.org/10.18343/jipi.23.3.246.

Gustiana C, Irwanto. 2017. Pengaruhbiaya produksi, pengalaman, dan keterampilan terhadap pendapatan usahatani kakao (Theobroma cacao) di Kecamatan Karang Baru Kabupaten Aceh Tamiang. Jurnal AGRISAMUDRA 4(2): 67-76. 
https://doi.org/10.33059/jpas.v4i2.286.

Elly FH. 2009. Analisis perilaku ekonomi rumah tangga petani usaha ternak sapi kelapa dalam menghadapi biaya transaksi di Kabupaten Bolaang Mongondow. Jurnal Pengkajian dan Pengembangan Teknologi Pertanian 12(3): 210 - 219.

Haris WA, Falatehan AF. 2017. Analisis peranan subsektor tanaman pangan terhadap perekonomian Jawa Barat. Journal of Regional and Rural Development Planning 1(3): 231-242. https://doi.org/10.29244/jp2wd.2017.1.3.231242.

Isnanda AN, Ani HM, Suyadi B. 2017. Pengaruh biaya usahatani buah naga terhadap keuntungan para petani buah naga di Desa Temurejo Kecamatan Bangorejo Kabupaten Banyuwangi. Jurnal Pendidikan Ekonomi: Jurnal Ilmiah Ilmu Pendidikan, Ilmu Ekonomi, dan Ilmu Sosial 11(1): 2-29. https://doi.org/10.19184/jpe. v11i1.4993.

LeonardoWJ, Bijman J, Slingerland MA. 2015. Combining transaction cost economics and farming systems theory to analyse farmer participation in value chains. Outlook in Agriculture 44(3): 207-214. https://doi. org/10.5367/oa.2015.0212.

Masithoh D. 2016. Biaya transaksi sistem resi gudang [thesis]. Bogor: Institut Pertanian Bogor.

Mohamad MAA, Darwanto D, Soeratno SH. 2014. Analisis biaya transaksi jagung hibrida di Provinsi Gorontalo. Jurnal SEPA 11(1): 49-54. https://doi.org/10.20961/sepa.v11i1.42249.

Normansyah D, Rochaeni S, Humaerah AD. 2014. Analisis pendapatan usahatani sayuran di kelompok Tani Jaya, Desa Ciaruten Ilir, Kecamatan Cibungbulang, Kabupaten Bogor. Jurnal Agribisnis 8(1): 29-44. https://doi. org/10.15408/aj.v8i1.5127.

Otekunrin OA, Momoh S, Ayinde IA. 2019. Smallholder farmers' market participation: concepts and methodological approaches from Sub-Saharan Africa. Current Agriculture Research Journal 7(2): 139-157. http://dx.doi.org/10.12944/ CARJ.7.2.02.

Purwanto AZ, Hadayani, Muis A. 2015. Analisis produksi dan pendapatanusahatanijagung hibrida di Desa Modo Kecamatan Bukal Kabupaten Buol. Jurnal Agroland 22(3): 205-215.

[Pusdatin] Pusat Data dan Sistem Informasi Pertanian. 2018. Outlook Komoditas Pertanian Tanaman

\section{Pangan Jagung. Indonesia: Kementrian} Pertanian.

Rachman NM, Cahyadi ER, Hardjomidjojo H. 2017. Biayatransaksi dan nilai tambah pada rantai pasok daging sapi di Kota Bogor. Jurnal Manajemen dan Agribisnis 14(1): 22-31. https:// doi.org/10.17358/jma.14.1.22.

Saidah Z, Harianto, Hartoyo S, Asmarantaka RW. 2019. Transaction cost analysis on revenues and profits of red chili farming. Jurnal Manajemen dan Agribisnis 16(1): 66-76. https://doi. org/10.17358/jma.16.1.66.

Sucihatiningsih DWP, Waridin. 2010. Model penguatan kapasitas kelembagaan penyuluh pertanian dalam meningkatkan kinerja usahatani melalui transaction cost. Jurnal Ekonomi Pembangunan 11(1): 13-29. https://doi.org/10.23917/jep. v11i1.332.

Sultan H, Rachmina D. 2016. Pengaruh biaya transaksi terhadap keuntungan usahatani kedelai di Kabupaten Lamongan, Jawa Timur. Forum Agribisnis 6(2): 161-178. https://doi. org/10.29244/fagb.6.2.161-178.

Susianti, Abd. Rauf R. 2013. Analisis faktor - faktor yang mempengaruhi pendapatan usahatani jagung manis. Jurnal Agrotekbis 1(5): 500-508.

Tahir AG, Suddin AF. 2017. Analisis pendapatan usahatani jagung pada lahan sawah dan tegalan di Kecamatan Ulaweng, Kabupaten Bone Sulawesi Selatan. Jurnal Galung Tropika 6(1): 1-11.

Vipriyanti NU. 2018. Teori dan Aplikasi Ekonomi Kelembagaan bagi Perencana Pembangunan. Denpasar: Fakultas Pertanian, Universitas Mahasaraswati Denpasar.

Williamson OE. 2000. The New Institutional Economics: Taking Stock, Looking Ahead. Journal of Economic Literature 38(3): 595-613. https://doi.org/10.1257/jel.38.3.595.

Yustika AE. 2008. The Transaction Cost of Sugarcane Farmers: An Explorative Study. Jurnal Ekonomi dan Bisnis Indonesia 23(3): 283-301.

Zulfiandri, Maarif MS, Hermawan A, Hardjomidjojo H. 2017. Biayatransaksi dan benefit cost pada integrasi vertikal rantai nilai agroindustri kakao skala kecil. Jurnal Manajemen dan Agribisnis 14(3): 187-197. https://doi.org/10.17358/ jma.14.3.187.

Zulkarnain, Mangiring W. 2017. Analisis biaya transaksi pada kelembagaan pertanian gapoktan penerima program Pengembangan Usaha Agribisnis Pedesaan (PUAP) di Desa Raman Aji 
Kecamatan Raman Utara Kabupaten Lampung Timur. Jurnal Penelitian Pertanian Terapan 17(3): 186-196. https://doi.org/10.25181/jppt. v17i3.325.
Zulkarnain, Zakaria WA, Haryono D, Murniarti K, Affandi M. 2019. Transactioncost structure on agribusiness system of cassava in Lampung Province. Revista de Clencias Humanasy Sociales 35(21): 2900-2925. 